Gut, 1972, 13, 903-906

\title{
Reaginic hypersensitivity in ulcerative colitis
}

\author{
D. P. JEWELL AND S. C. TRUELOVE \\ From the Nuffield Department of Clinical Medicine, Radcliffe Infirmary, Oxford
}

SUMMARY Reaginic hypersensitivity in ulcerative colitis has teen investigated in respect of a hypersensitivity to the cow's milk proteins and the frequency of atopic asthma, hay fever, and eczema. Intradermal tests were frequently positive, especially to casein, but the results did not differ from those found in healthy individuals and in groups of patients with Crohn's disease, hypolactasia, and the irritable colon syndrome. No circulating IgE-specific antibodies to the milk proteins were found. An increased frequency of atopic diseases was found in patients suffering from ulcerative colitis $(15.7 \%)$ and Crohn's disease $(13.3 \%)$ compared with the findings in a control group $(1.2 \%)$.

It is concluded that, if an allergy to milk proteins is a factor in the pathogenesis of ulcerative colitis, it is not mediated by reaginic antibodies. It is possible, however, that the frequent occurrence of atopy indicates a susceptibility to develop reaginic responses even though this mechanism does not apply to the milk proteins.

Clinical observation has suggested that an allergy to dietary proteins may be a factor in the aetiology of ulcerative colitis (Andresen, 1942; Mackie, 1942; Rowe, 1942; Sarles, Deck, Chalvet, and Ambrosi, 1959). The commonest food incriminated has been cow's milk and this was supported by the fact that patients in remission on a milk-free diet rapidly relapsed when challenged with milk (Truelove, 1961). Subsequently, a controlled dietary trial showed that one in five patients appeared to benefit from a milkfree diet (Wright and Truelove, 1965a). Rowe, Rowe, and Uyeyama (1955) claimed that an allergy to pollen was an important factor in some patients with the disease.

Andresen (1942) and Rowe (1942) stressed that skin tests were unhelpful in selecting the patients who would benefit from a milk-free diet. However, Rider, Moeller, Deveraux, and Wright (1960) found that patients frequently reacted within five minutes to various allergens-such as milk, wheat or egginjected into the rectal mucosa. When the relevant allergen was removed from the diet, the patient remained in remission but no long-term study has been reported. Taylor and Truelove (1961) found that patients with ulcerative colitis had raised antibody titres to the milk proteins when compared with control subjects but Wright and Truelove (1965b) were unable to predict from the height of the antibody titres whether or not an individual patient would benefit from a milk-free diet.

Received for publication 7 September 1972.
The possibility that milk sensitivity in ulcerative colitis might be mediated by reaginic antibodies has been investigated in the present study by the use of intradermal testing and by measuring IgE-specific antibodies in serum, as it is now established that IgE is the carrier of reaginic antibody (Ishizaka and Ishizaka, 1967). The frequency of other reaginmediated diseases such as asthma, hay fever, and atopic eczema occurring in ulcerative colitis has also been investigated.

\section{Methods}

PATIENTS STUDIED

The patients studied were those with classical ulcerative colitis diagnosed on the basis of a history of bloody diarrhoea, on the characteristic sigmoidoscopic appearances and the histological appearances of the rectal biopsy, and on the changes seen on the barium enema. The results obtained were compared with those obtained from a control group of healthy volunteers and from groups of patients with Crohn's disease, the irritable colon syndrome, hypolactasia, and coeliac disease.

SKIN TESTS

Purified casein, $\alpha$-lactalbumin, and $\beta$-lactoglobulin were supplied by Dr R. Lyster of the National Institute for Research in Dairying. They had been prepared by the method of Gunther, Aschaffenberg, Matthews, Parish, and Coombs (1960). For intra- 
dermal testing, the purified proteins were made up in a $1 \%$ solution containing $0.5 \%$ phenol by Bencards.

Of each solution, $0.01-0.02 \mathrm{ml}$ was injected intradermally into the forearm and the result was read at 10 minutes. A control solution containing $0.5 \%$ phenol was also injected. The results were assessed by measuring the diameter of the wheal and were recorded as negative, $1 \mathrm{~cm}$ or less (positive), greater than $1 \mathrm{~cm}$ (strongly positive).

\section{IgE ANTIBODIES}

Antibodies to the milk proteins of the IgE immunoglobulin class were measured using the red-celllinked antigen-antiglobulin reaction. Details of the method have been published elsewhere (Jewell and Truelove, 1972). Specific IgE antiserum was supplied by Dr D. S. Rowe (WHO). The antiserum had been prepared by immunizing sheep with the $\mathrm{Fc}$-fragment of IgE isolated from a pool of African sera. It had been absorbed with normal serum of low IgE content and shown to be specific for IgE by immunoelectrophoresis and by gel diffusion. It was used at a dilution of 1 in 500 .

\section{Results}

\section{SKIN TESTS}

The results of skin testing with the purified milk proteins are shown in Table I. It can be seen that the percentages of positive reactions obtained in each diagnostic category were similar. When the positive reactions were divided into those that were positive $(1 \mathrm{~cm}$ or less in diameter) and those that were strongly positive (greater than $1 \mathrm{~cm}$ ), no differences emerged between the various groups of patients and the healthy control group.

\begin{tabular}{|c|c|c|c|c|}
\hline \multirow[t]{2}{*}{ Diagnosis } & \multirow{2}{*}{$\begin{array}{l}\text { No. } \\
\text { Tested }\end{array}$} & \multicolumn{3}{|c|}{ Percentage Positive Tests } \\
\hline & & Casein & $\begin{array}{l}\alpha-\text { Lact- } \\
\text { albumin }\end{array}$ & $\begin{array}{l}\text { B-Lacto- } \\
\text { globulin }\end{array}$ \\
\hline $\begin{array}{l}\text { Ulcerative colitis } \\
\text { Crohn's disease } \\
\text { Hypolactasia } \\
\text { Normal } \\
\text { Irritable colon syndrome }\end{array}$ & $\begin{array}{l}39 \\
19 \\
11 \\
20 \\
19\end{array}$ & $\begin{array}{l}59 \\
68 \\
45 \\
75 \\
68\end{array}$ & $\begin{array}{l}10 \\
21 \\
10 \\
20 \\
16\end{array}$ & $\begin{array}{l}13 \\
12 \\
18 \\
20 \\
16\end{array}$ \\
\hline
\end{tabular}

Table I Frequency of positive skin tests to milk proteins

When the results from all the 111 subjects were combined, $64 \%$ of them showed a positive reaction to casein, $14 \%$ to $\alpha$-lactalbumin, and $16 \%$ to $\beta$ lactoglobulin.

All the subjects who were skin tested to the milk proteins had been tested for circulating antibodies to the milk proteins using the red-cell-linked antigenantiglobulin reaction (Jewell and Truelove, 1972).
No correlation existed between the presence of $\operatorname{IgA}$ or IgG antibodies in the serum and a positive skin test. Subjects who had direct agglutinating antibodies to casein in their sera were more likely to have positive skin tests than were subjects without such antibodies although the differences are only at the borderline of statistical significance (Table II).

\begin{tabular}{llcl}
\hline Result of Skin Test & \multicolumn{2}{l}{ Direct Agglutinating Antibodies } & Total \\
\cline { 2 - 3 } & Negative & Positive & \\
\hline Negative & 39 & 1 & 40 \\
Weakly positive & 47 & 8 & 55 \\
Strorgly positive & 13 & 3 & 16 \\
Total & 99 & 12 & 111 \\
\hline
\end{tabular}

Table II Results of skin tests to casein correlated with the presence of direct agglutinating antibodies to casein in serum ${ }^{1}$

${ }^{1}$ By Fisher's exact test, $P=0.062$. When the positive skin tests are grouped together, $P=0.053$.

\section{IgE ANTIBODIES}

Sera from 167 subjects were tested. They were obtained from patients with ulcerative colitis (51), Crohn's disease (30), hypolactasia (13), the irritable colon syndrome (24), and coeliac disease (11). Sera from 38 healthy volunteers, who had no history of milk intolerance, were also tested.

No IgE antibodies to the milk proteins were detected in any of the sera tested. Three patients (two with ulcerative colitis and one with the irritable colon syndrome), who had strongly positive skin tests to all three proteins, were studied in more detail. None of the three sera contained direct agglutinating antibodies and they were therefore tested using anti-IgE antiserum diluted in a range from 1 in 50 to 1 in 5000 . No IgE antibodies could be demonstrated.

\section{FREQUENCY OF ATOPY}

Eight patients with ulcerative colitis $(15.7 \%)$ and four patients with Crohn's disease $(13.3 \%)$ had asthma, hay fever, or atopic eczema, either singly or in combination (Table III). In contrast, only one patient $(1.2 \%)$ out of the other 86 patients studied had an atopic disease. The greater frequency of these

\begin{tabular}{lllll}
\hline Diagnosis & $\begin{array}{l}\text { Total } \\
\text { No. }\end{array}$ & Asthma & $\begin{array}{l}\text { Hay } \\
\text { Fever }\end{array}$ & Eczema \\
\hline Ulcerative colitis & 51 & 4 & 6 & 3 \\
Crohn's disease & 30 & 2 & 1 & 2 \\
Hypolactasia & 13 & 0 & 0 & 0 \\
Coeliac disease & 11 & 0 & 0 & 0 \\
Normal controls & 38 & 0 & 0 & 0 \\
Irritable colon syndrome & 24 & 0 & 0 & 1 \\
\hline
\end{tabular}

Table III The frequency of atopic conditions 
diseases observed in the patients with ulcerative colitis or Crohn's disease, compared with the control subjects, was statistically significant $\left(\chi^{2}=10.97\right.$, $\mathrm{n}=2, \mathrm{P}<0.01$ ).

A higher proportion of the patients with these atopic diseases gave positive skin tests to the purified cow's milk proteins compared with the results obtained for the whole series of patients (Table IV). Patients with asthma, hay fever, or eczema did not have greater titres of circulating antibodies to the milk proteins than did those subjects who did not have these diseases.

\begin{tabular}{|c|c|c|c|}
\hline \multirow[t]{2}{*}{ Protein } & \multirow{2}{*}{$\begin{array}{l}\text { No. of } \\
\text { Patients }\end{array}$} & \multicolumn{2}{|c|}{ Skin Tests } \\
\hline & & $-v e$ & $+v e$ \\
\hline \multicolumn{4}{|l|}{ Asthma } \\
\hline Casein & & & \\
\hline $\begin{array}{l}\alpha \text {-Lactalbumin } \\
\beta \text {-Lactoglobulin }\end{array}$ & $\begin{array}{l}5 \\
5\end{array}$ & $\begin{array}{l}3 \\
2\end{array}$ & $\begin{array}{l}2 \\
3\end{array}$ \\
\hline \multicolumn{4}{|l|}{ Hay fever } \\
\hline Casein & 5 & 1 & 4 \\
\hline$\alpha$-Lactalbumin & 5 & 2 & 3 \\
\hline$\beta$-Lactoglobulin & 5 & 2 & 3 \\
\hline \multicolumn{4}{|l|}{ Eczema } \\
\hline Casein & 5 & 1 & 4 \\
\hline$\alpha$-Lactalbumin & 5 & 1 & 4 \\
\hline$\beta$-Lactoglobulin & 5 & 1 & 4 \\
\hline
\end{tabular}

Table IV Results of skin tests in patients with ulcerative colitis or Crohn's disease with atopic conditions

\section{Discussion}

The results of this study do not support the hypothesis that a reaginic hypersensitivity to cow's milk proteins is a factor in the pathogenesis of ulcerative colitis. Although wheal and flare reactions to the purified milk proteins injected intradermally were commonly found, the frequency of positive reactions did not differ from that seen in the other groups of patients studied or in the group of healthy individuals. Furthermore, no circulating IgE specific antibodies to the milk proteins were demonstrated.

When the results of all the 111 subjects who were skin tested are combined, $64 \%$ reacted to casein, $14 \%$ to $\alpha$-lactalbumin and $16 \%$ to $\beta$-lactoglobulin. This indicates that sensitization to the milk proteins is common and the higher proportion of positive tests to casein compared with the other two proteins probably reflects the protein composition of milk. The casein in cow's milk comprises $80 \%$ of the total protein content (approximately $2.3 \mathrm{~g} / 100 \mathrm{ml}$ whole milk) whereas the whey proteins, which include $\alpha$-lactalbumin and $\beta$-lactoglobulin, are contained in the remaining $20 \%$.

There is now good evidence that immediate type I skin tests are mediated by IgE antibody bound to cells, probably mast cells. The P-K titre correlates well with the titre of IgE specific antibody (Ishizaka, Ishizaka, and Hornbrook, 1966) and the P-K reaction can be blocked by IgE (Stanworth, Humphrey, Bennich, and Johansson, 1967). Furthermore, a good correlation exists between the presence of IgE-specific antibody and positive skin provocation tests in situations of clinical hypersensitivity (Wide, Bennich, and Johansson, 1967; Stenius and Wide, 1969).

The failure to find IgE antibodies to milk proteins in the serum of patients who gave positive skin reactions may have a number of explanations. Milk proteins are absorbed from the gastrointestinal tract in minute amounts and may therefore provide a weak antigenic challenge. Since IgE is strongly homocytotropic, small amounts of specific antibody formed in response to such a challenge may be largely bound to cells, and the amount circulating in the blood may therefore be too small to measure. None of the patients who had positive reactions had an obvious clinical allergy to milk and it is possible that the presence of blocking antibody not only prevented clinical allergy, but also prevented the demonstration of IgE-specific antibody. Finally, the red-cell-linked, antigen-antiglobulin test may not have been sensitive enough to detect IgE antibodies. However, it has provided a sensitive and reliable method for the detection of antibodies of other immunoglobulin classes (Coombs, Jonas, Lachmann, and Feinstein, 1965; Jewell and Truelove, 1972), and it has been used to detect IgE antibodies to castor bean in patients with castor bean allergy (Coombs, Hunter, Jonas, Bennich, Johansson, and Panzani, 1968). Another possibility is that the presence of a direct agglutinating antibody masked low titres of IgE antibody.

The increased frequency of asthma, hay fever, and eczema observed in patients with ulcerative colitis and Crohn's disease was an interesting finding and confirms the observations of Hammer, Ashurst, and Naish (1968) who found a similar increased frequency compared with controls. Since these atopic diseases are mediated by reaginic antibody and the affected subjects usually have raised levels of IgE in their serum (Berg and Johansson, 1969; Juhlin, Johansson, Bennich, Högman, and Thyresson, 1969), it is possible that patients with ulcerative colitis or Crohn's disease may be prone to develop reaginmediated allergies. If such a susceptibility plays a part in the aetiology of the two diseases, then the allergens involved have yet to be defined. Certainly the present study indicates that a reaginic response to cow's milk proteins is not involved in either ulcerative colitis or Crohn's disease, but does not exclude such a response to other exogenous allergens. 


\section{References}

Andresen, A. F. R. (1942). Ulcerative colitis-an allergic phenomenon. Amer. J. dig. Dis., 9, 91-98.

Berg, T., and Johansson, S. G. O. (1969). IgE concentrations in children with atopic diseases. Int. Arch. Allergy, 36, 219-232.

Coombs, R. R. A., Hunter, A., Jonas, W. E., Bennich, H., Johansson, S. G. O., and Panzani, R. (1968). Detection of IgE(IgND) specific antibody (probably reagin) to castor-bean allergen by the red-cell-linked antigen-antiglobulin reaction. Lancet, 1, 1115-1118.

Coombs, R. R. A., Jonas, W. E., Lachmann, P. J., and Feinstein, A. (1965). Detection of IgA antibodies by the RCLAAR: antibodies in the sera of infants to milk proteins. Int. Arch. Allergy, 27, 321-327.

Gunther, M., Aschaffenburg, R., Matthews, R. H., Parish, W. E., and Coombs, R.R. A. (1960). The level of antibodies to the proteins of cow's milk in the serum of normal human infants. Immunology, 3, 296-306.

Hammer, B., Ashurst, P., and Naish, J. (1968). Diseases associated with ulcerative colitis and Crohn's disease. Gut, 9, 17-21.

Ishizaka, K., and Ishizaka, T. (1967). Identification of $\gamma \mathrm{E}$-antibodies as a carrier of reaginic activity. J. Immunol., 99, 1187-1198.

Ishizaka, K., Ishizaka, T., and Hornbrook, M. (1966). Physicochemical properties of reaginic antibody. V. Correlation of reaginic antibody with $\gamma \mathrm{E}$-globulin antibody. J. Immunol., 97, 840-853.

Jewell, D. P., and Truelove, S. C. (1972). Circulating antibodies to cow's milk proteins in ulcerative colitis. Gut, 13, 796-801.

Juhlin, L., Johansson, S. G. O., Bennich, H., Högman, C., and Thyresson, N. (1969). Immunoglobulin $E$ in dermatoses: levels in atopic dermatitis and urticaria. Arch. Dermat., 100, 12-16.
Mackie, T. T. (1942). Ulcerative colitis-an allergic phenomenon. (In discussion to Andresen.) Amer. J. dig. Dis., 9, 97.

Rider, J. A., Moeller, H. C., Devereaux, R. G., and Wright, R. R. (1960). The use of an intramucosal test to demonstrate food hypersensitivity in ulcerative colitis. Acta allerg. $(K b h) ., 15$, Suppl. 7, 486-494.

Rowe, A. H. (1942). Chronic ulcerative colitis-allergy in its etiology. Ann. intern. Med., 17, 83-100.

Rowe, A. H., Rowe, A., Jr., and Uyeyama, K. (1955). Chronic ulcerative colitis due to pollen allergy, with six case reports. Acta med. scand., 152, 139-151.

Sarles, H., Deck, M., Chalvet, H., and Ambrosi, L. (1959). Rectocolite hémorragique et allergie alimentaire. Arch. mal. appar. Dig., 48, 907-925.

Stanworth, D. R., Humphrey, J. H., Bennich, H., and Johansson, S. G. O. (1967). Specific inhibition of the Prausnitz-Küstner reaction by an atypical human myeloma protein. Lancet, 2 , 330-332.

Stenius, B., and Wide, L. (1969). Reaginic antibody (IgE), skin, and provocation tests to Dermatophagoides culinae and house dust in respiratory allergy. Lancet, 2, 455-458.

Taylor, K. B., and Truelove, S. C. (1961). Circulating antibodies to milk proteins in ulcerative colitis. Brit. med. J., 2, 924-929.

Truelove, S. C. (1961). Ulcerative colitis provoked by milk. Brit. med. J., 1, 154-160.

Wide, L., Bennich, H., and Johansson, S. G. O. (1967). Diagnosis of allergy by an in-vitro test for allergen antibodies. Lancet, 2 , 1105-1107.

Wright, R., and Truelove, S. C. (1965a). A controlled therapeutic trial of various diets in ulcerative colitis. Brit. med. J., 2, 138-141.

Wright, R., and Truelove, S. C. (1965b). Circulating antibodies to dietary proteins in ulcerative colitis. Brit. med. J., 2, 142-144. 